\title{
Corporate social responsibilities of stakeholders in terms of secure tourism at disasters and sustainable tourism governance
}

\author{
Zerrin Toprak Karaman $^{1}$
}

\begin{abstract}
In the report published by the United Nations Office for Disaster Risk Reduction, it is stated that 90 percent of 6,457 natural disasters have been caused by floods, storms, hot air waves, drought, and other excessive climatic movements in the last 20 years. Tourists are sent from Turkey to important tourism centers of the world. Turkey is an attractive country with significant potential for different types of tourism movements. Turkey is gradually becoming one of the countries which are negatively affected by the natural disasters occurring depending on climate changes. Likewise, whirlwinds have almost become a routine in the Mediterranean Region, particularly in Mersin province. The dense population in touristic regions is also of similar importance in terms of terrorist attacks - another type of man-made disasters. The chaotic environment created by disasters also has a feature which might be utilized as a suitable opportunity for terror as well. New problem areas have been added to the service flow and problems within the ethical behavior codes of tourism agencies that have gained a classical value. How those who manage tourism can govern the possible risk and crisis processes and, if available, their acquired experiences that they have developed to ensure the safety of tourists have gradually become more important in the scenario of secure tourism. In conclusion, this proposed study envisages model study based on the cooperation networks likely to be developed with the relevant public, private, and civil actors by taking the views of the stakeholders in the tourism sector such as the hotels and agencies managing the Domestic and Foreign Tourism activities in İmir in addition to the issue of what kind of a strategic action plan they make and should be made with respect to safe tourism in important touristic areas.
\end{abstract}

Keywords: Secure Tourism, Risk and Crisis Analyses, Tourism Stakeholders, Disasters

To cite this article: Toprak Karaman, Z. (2017). Corporate social responsibilities of stakeholders in terms of secure tourism at disasters and sustainable tourism governance. Journal of Tourism Theory and Research, 3(2), 66-78. DOI: 10.24288/jttr.317665

${ }^{1}$ Prof. Dr., Dokuz Eylul University, İzmir, Turkey, zerrin.toprak@deu.edu.tr 


\section{Introduction}

Turkey is an attractive country with significant potential for different types of tourism movements. Besides, tourists are sent from Turkey to important tourism centers of the world. However, it is gradually becoming one of the countries which are negatively affected by any kind of disasters, terrorist attacks at the first step and in the future, and the natural disasters occurring depending on climate changes. Besides, another possibility can occur: The chaotic environment created by disasters also has a feature which might be utilized as a suitable opportunity for terror as well. New problem areas have been added to the service flow and problems within the ethical behavior codes of tourism agencies that have gained a classical value.

Unfortunately, all these possibilities are not the negative scenarios. How those who manage tourism can govern the possible risk and crisis processes and, if available, their acquired experiences that they have developed to ensure the safety of tourists have gradually become more important in the scenario of secure tourism. All these factors are gradually reducing the share of tourism in the GNP. However, the tourism revenues in the GNP rose to $5.4 \%$ in 2002 and to $6.2 \%$ in 2015 from small figures like $0.6 \%$ in 1980 (http://www.tursab.org.tr/tr/turizm-

verileri/istatistikler/). In the final analysis, the tourism revenues regressed by $-29.7 \%$ for the $2015-2016$ period (http://yigm.kulturturizm.gov.tr/).

In the report published by the United Nations Office for Disaster Risk Reduction, it is stated that 90 percent of 6,457 natural disasters have been caused by floods, storms, hot air waves, drought, and other excessive climatic movements in the last 20 years (https://www.unisdr.org/archive/46793). The countries most influenced by natural disasters are the USA, China, India, the Philippines, and Indonesia. These countries also have regions with significant potential for tourism.

Turkey is also evaluated in terms of disaster risks, it is seen that according to the index ranking created depending on the data obtained from the Index for Risk Management (INFORM), it is most confronted with the risks of earthquakes, terrorist clashes, tsunamis, floods, and drought, respectively (http://www.informindex.org/,2017). The fact that the tornadoes (2015) seen above the sea near the coast in İstanbul and İzmir provinces in the recent years and watched with bewilderment and fear have appeared in the first news and the losses caused in the agricultural sector by the damage induced by the tornadoes on the Mediterranean coasts, particularly in Mersin, since 2009 to present are no more the first and sole phenomenon. The experiencing of no tsunami in Turkey recently despite the presence of its examples like the one experienced in İzmir in the 1688 s causes it to be a matter which never comes to mind on the agenda of the public opinion. Nevertheless, it is at the top ranks among the possible disaster risks in the scientific predictions, which should be highlighted for disaster managers.

How did the contents of this presentation develop? The overflowing of the Seine River and the shutting down of the Louvre Museum last June (2 June 2016) highlighted the issues of tourism security and conservation of historical assets at natural disasters. However, the probability of a terrorist attack was also overcome on these days. Some 84 people died in Nice on 15 July 2016, and then a series of terrorist attacks spread like a virus from one country to another in Europe. Most events took place in the crowded areas which attracted tourists. Crowded areas have become good targets for terrorist attacks. Therefore, it is essential to make studies on the fact that it becomes important to review the new security indicators of tourism.

Briefly, this proposed study envisages a model study based on the cooperation networks likely to be developed with the relevant public, private, and civil actors by taking the views of the stakeholders in the tourism sector such as the hotels and agencies managing the Domestic and Foreign Tourism activities in İzmir in addition to the issue of what kind of a strategic action plan they make and should be made with respect to secure tourism in important touristic areas.

\section{Sustainable tourism and its structural change}

Whilst the issue of tourism was initially associated with human rights and the right to travel with the approaches "the Universal Declaration of Human Rights adopted by the General Assembly of the United Nations "Rest, leisure, reasonable limitation of working hours and periodic holidays with pay, as well as remuneration for public holidays" $(1948,1966)$ and 
" Everyone shall be free to leave any country, including his own" (1966), it has been associated with the environmental protection-use balance and a network with a cultural framework in which the principles of international universal environmental policies are taken as the basis by the World Tourism Organization (WTO) since the 1990s (Hague Declaration on Tourism,1989).

The WTO provided the following phrases in the definition of sustainable tourism development: i) Protection of the environment from corruption and transformation, in which it interacts human or not, ii) Resume the system of cultural integrity, ecological processes, biological diversity and life-sustaining, and iii) Satisfy the economic, social and aesthetic needs of people in the destination and manage in a way that can meet the needs of future generations (1998). Indeed, this development has also changed the perception of safety and security in tourism periodically since the 1950s in terms of influencing (Kôvári and Zimányi , pp.60).

To provide an example in order to give an idea about the determination of the situation in the first decade of the 2000s, the issue of "secure tourism" was not directly mentioned anywhere in the Report (SurdurulebilirTurizm-Rapor, 2012, pp. 24) prepared by the Turkish Industry and Business Association (Turkish: TÜSIAAD) on the basis of the 12 fundamental principles that the World Tourism Organization had developed to provide the theme of "Sustainable Tourism" "as it was not considered necessary".

However, even though the issue of security was not directly addressed, the concepts of "local and social welfare" and "satisfaction" (Report, pp. 20) generally stood out in the Report by the TUSIAD. In this report, it is mentioned that the tourism sector of Turkey will grow by about $3 \%$ in the next decade.

Here are the themes of priority in the international meetings showing the conceptual development of the studies on Sustainable Tourism: 4 November 1966, entitled "International Tourist Year"; 15 December 1998, entitled "Proclamation of 2002 as the International Year of Ecotourism"; 20 December 2010, entitled "Global Code of Ethics for Tourism"; 20 December 2013, entitled "Sustainable tourism and sustainable development in Central America"; and 19
December 2014, entitled "Promotion of sustainable tourism, including ecotourism, for poverty eradication and environmental protection" (http://www.un.org). When we look at the present, we see that the United Nations $70^{\text {th }}$ General Assembly has designated 2017 as the International Year of Sustainable Tourism for Development (http://www.un.org.tr/2017).

The studies under this heading were regarded as an opportunity for ensuring the attainment of the sustainable tourism objective of the practice of governance (public and private sector decision-makers and the NGOs). In the context of the universal 2030 Agenda for Sustainable Development and the Sustainable Development Goals (SDGs), the International Year aims to support a change in policies, business practices and consumer behavior towards a more sustainable tourism sector than can contribute to the SDGs.

Recalling the outcome document of the United Nations Conference on Sustainable Development, entitled "The future we want", the year 2017 will promote tourism's role in the following five key areas:

(1) Inclusive and sustainable economic growth

(2) Social inclusiveness, employment, and poverty reduction

(3) Resource efficiency, environmental protection, and climate change

(4) Cultural values, diversity, and heritage

(5) Mutual understanding, peace, and security.

Briefly, while the tourism studies had been concerned with the issue of competition likely to be associated with the protection and use of the natural environment and with the issue of the financing support required by tourism until the last two years (The year 2015 might be the beginning of asymmetric terror attacks), the understanding of providing the sustainability of tourism unfortunately and additionally with "competition in human-centric security" has now become the issue of priority. It is seen that whether in the case of nature or humaninduced disasters, the issue of security is a value which is intended to be provided in relation to local and social welfare as a whole.

In the 1992 United Nations report (http://www.un.org/1992), the concept of security is defined as the phenomena which may occur either suddenly or slowly for economic, political, and nature- 
induced reasons and which threaten the flow in everyday life. Under the current conditions, these phenomena are developed as community security, public safety and security, political security, cyber security threats, health and safety risk, natural disasters security threats, man-made hazards (terrorist attack), environmental security, legal protection, reliable insurance services, destination logistics online information, etc. This subject has been examined below with its main elements within the general theme of human security.

\section{National security and human security}

National security is a concept which suggests that a government, with its parliament, should protect the state, its citizens, and the physical integrity of the territories against any "national" and "international" threats through various power projections such as political power, diplomacy, economic power, and military power and take preventive measures against crises.

The definition of security is less extensive than that embraced by the super powers. Security means "the protection and preservation of the minimum core values of any nation: political independence and territorial integrity" (Maniruzzaman, 1982, pp. 15 ). With its qualities, the concept of national security does not have a single accepted definition. Today it is evaluated as a comprehensive concept which encompasses all values that provide the sustainability of a state with its country and nation such as not only military security but also economic security, security of the natural environment, energy security, and border security. Security threats include not only conventional enemies such as the other states outside the border but also the drug cartels and criminal organizations which create violence by using force. Natural disasters and the events which cause heavy environmental damage are also examined within the scope of security.

The studies which strengthen the strategic infrastructural and superstructural equipment of settlements, the studies of economic support to enhance social resistance, the studies of preparation for civil defense as well as disaster and emergency management, the intelligence studies to prevent terrorist attacks, determination of espionage, and military activities are important administrative measures to ensure national security.

The Commission on Human Security (CHS) advocates that the need for a new paradigm of security has occurred due to the current conditions. Firstly, there is a need for a human assurance in response to the complexity of old and new security threats from chronic and persistent poverty to ethnic violence, human trafficking, climate change, conditions for health security, international terror, and sudden economic and financial downturns as well as their interrelationships. This is because such threats alone go beyond the traditional concepts of security coming from foreign countries or cross-border areas due to their tendency to have cross-border and transnational qualities. Secondly, there is a need for a comprehensive approach which uses comprehensive new opportunities and structures for the integrated settlement of such threats that occur against the security of people. It is seen that the threats occurring against human security cannot be solved with classical security measures (by using weaponry) alone (http://www.un.org/humansecurity/sites/); hence, complementarily, there is a need for new national and international consensus which acknowledges the interdependence among development, human rights, and national security considering a wide network of relationships. In the final analysis, the networks of relationships between national security and various types of security appear to have an indissociably complementary quality.

The final report by the CHS (CHS, 2003, pp.4) associates human security with protecting the freedom of human beings - their vital center. Protecting a free human being against severe and widespread threats and enabling him/her to survive constitute the building blocks of an honorable life. The idea that this matter should at the same time be considered together with political, social, natural, economic, military, and cultural systems is advocated. The issues with respect to the providing of human security constitute an interdisciplinary concept which brings together "the human elements" of security, right, and development. The basic elements which take human security as the basis are as follows: i) It is multisectoral, ii) It is comprehensive, iii)It has original conditions, iv) It is preventive. 
As a people-centered concept, human security places the individual at the 'center of analysis'. Consequently, it deals with a wide range of conditions complicating or eliminating survival or threatening life. Human security at the same time indicates the threshold below which the human life, which must be honorable, is unbearably threatened. The causes of insecurity require an examination of such issues as health, environment, and food on the personal and community scales. These issues are also associated with political security.

Table 1. Possible threats in human security

\begin{tabular}{|l|l|}
\hline $\begin{array}{l}\text { Types of } \\
\text { Security }\end{array}$ & Examples of Basic Threats \\
\hline $\begin{array}{l}\text { Economic } \\
\text { Security }\end{array}$ & Persistent poverty and unemployment \\
\hline Food Security & $\begin{array}{l}\text { Hunger and famine as well as } \\
\text { terrorism* }\end{array}$ \\
\hline $\begin{array}{l}\text { Health } \\
\text { Security }\end{array}$ & $\begin{array}{l}\text { Deadly Infectious Diseases*, unsafe } \\
\text { food, malnutrition, and lack of access } \\
\text { to basic health services }\end{array}$ \\
\hline $\begin{array}{l}\text { Environmental } \\
\text { Security }\end{array}$ & $\begin{array}{l}\text { Environmental } \\
\text { inadequacy of resources, natural } \\
\text { disasters, terrorism in a chaotic } \\
\text { environment*, and pollution }\end{array}$ \\
\hline $\begin{array}{l}\text { Personal } \\
\text { Security }\end{array}$ & $\begin{array}{l}\text { Physical violence, crime, terrorism, } \\
\text { domestic violence, and child labor }\end{array}$ \\
\hline $\begin{array}{l}\text { Community } \\
\text { Security }\end{array}$ & $\begin{array}{l}\text { Inter-ethnic, religious and other } \\
\text { identity-based tensions and terrorism* }\end{array}$ \\
\hline $\begin{array}{l}\text { Political } \\
\text { Security }\end{array}$ & $\begin{array}{l}\text { Political repression, violations of } \\
\text { human rights, domestic and foreign* }\end{array}$ \\
\hline
\end{tabular}

Source: See UN Human Security in Theory and Practice, 2009, pp.6: Based on the UNDP Human Development Report of 1994 (* added by the author).

The following types of security, which threaten human security, are interconnected. Each threat is connected with another and may create a domino effect. For instance, both violent conflicts may lead to deprivation and poverty and hence to resource depletion, infectious diseases, and inadequacies and problems in education and the threats may spread over a wider region in a specific country or area in an actionreaction relationship and lead to regional and national and even international security problems. This case of being affected, which might also come from the crossborder area, entails international security definitions for the clarification of the responsibility. Table 1, which evaluates the concept of human security by the United Nations Trust Fund for Human Security, is as follows.

\section{Tourism in Turkey and the effect of security}

Although this study does not aim to examine the overall problems of tourism, it will be appropriate to make a numerical evaluation in order to reveal the importance of the factor of security in reducing the market opportunities in the tourism sector. The number of foreign visitors coming to Turkey in 2016 decreased by $-30.05 \%$ as compared with that in 2015 , thereby regressing to 25 million 352 thousand and 213 people. The regression of the number of tourists coming from the Russian Federation in 2014, i.e. 4,479,049 people, to 866,256 people in 2016 (http://www.tursab.org.tr/ ) due to "the political crisis" between the two countries constitutes a good example of the fragility of tourism mobility.

Even though Turkey is an "attractive" holiday country for foreigners in terms of purchasing power, the factor of cheapness has lost its significance in rural and urban areas owing to "not feeling safe", which is due to the terror events. Tourism mobility is not regarded as positive at all from the present to the future for İzmir either, as is the case throughout Turkey. Likewise, according to the evaluations made for cruise tourism - an essential revenue item, whilst only 34 vessels docked at the Alsancak Port in 2016, this figure is "zero" for 2017. In spite of the rise in cruise tourism, which has a significant role in the promotion of İzmir, in the last decade, it is declared that there has been a regression in "tourist arrivals" owing to the terror events experienced in Turkey since 2015. In addition, the information that the firms of European origin have decided to halt their voyages to Turkey due to the scarcity of demands (http://www.turizmdebusabah.com/) has been shared with the public opinion, which reveals the seriousness of the situation. Figure 1 is important in that it demonstrates the risk awareness of the tourism sector in Turkey.

The issue of security includes two fundamental gradations: i) security of facilities (touristic) and ii) security of the country in terms of terrorist attacks. Moreover, "the sectoral security deficit" created by the openness of the tourism sector to national and crossborder impacts should also be taken into consideration. Although the tourism sector attaches importance to the issue of "terror", it also expects that government's formation of good political and economic relations, 
diplomatic language with its neighbors will stop the regression in the tourism sector.

Figure 1. Risk awareness in the tourism sector (20152017)

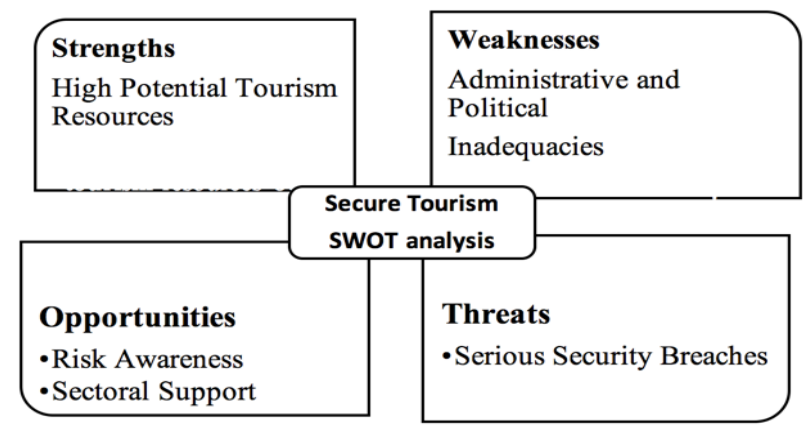

To evaluate sustainable secure tourism, 2 Brainstorming Meetings hosted by the Master's Degree Program in the Division of Disaster Management at Dokuz Eylul University were held in February and March. Evaluations of the issue were obtained from a total of 38 participants in both meetings $^{2}$. Upon the request of the sectoral representatives, a workshop on "Tourism and Security" will be held and action plans will be drawn up in May so as to develop these studies. Some issues likely to pose a risk for sustainable tourism are provided below by making use of the brainstorming notes.

\section{Risk factors in the sustainability of tourism}

When it is questioned whether the sector has prepared any strategy and crisis preventive action plan for the risks and apparent threats for Sustainable Tourism, the two basic matters below stand out.

- The sectoral stakeholders have no study that they have jointly developed, that is suitable for the definition of "terror" and that might be associated with the phenomenon of tourism either at the local or national level.

- In the previous years, particularly the local people, as the basic stakeholders, were given roles that would enhance participation "in the development from soft tourism to sustainable tourism" in tourism activities

(http://www.nfi.at/dmdocuments/NachhaltigerTouris mus EN.pdf).

\footnotetext{
${ }^{2}$ Views were formed with the participation of a total of 41 people - 13 university representatives, 3 public representatives, and 8 sectoral representatives in the first meeting ( $23^{\text {rd }}$ of February) as
}

- Under the current conditions, it is important to carry out integrated strategic studies to enhance security and eliminate possible threats also for tourists and settled foreigners as external stakeholders, along with the local people.

-Our Border and Cross-Border Neighbors regard the threat that Turkey is confronted with as an opportunity for themselves "in terms of attracting tourists".

- Tourism activities are essentially an international field of competition according to their subject. Therefore, depending on the political climate over which international relations predominate, security violations are converted into good opportunities for "tourist deterrence" in terms of foreign countries.

-No risk analysis or mapping on natural disasters and including touristic provinces has been made.

- The occurrence of no known and recorded problem with an impact on tourism in Turkey due to natural disasters has led to a delay in diagnosing the requirement for risk determination.

- In the context that natural disasters are generally suddenly-encountered threats, they do not cause a problem before travelling in terms of tourists. In other words, it is stated that they do not affect tourists very much.

- It is thought that the obligation that the governorship units make a risk analysis for each province according to their respective features is an opportunity for touristic regions.

In general, theoretical strategic plans on disaster management are drawn up in Turkey. These studies are accessible via the Internet. Nevertheless, it is rather hard to say that there has been a profound development throughout the country in preparing strategic action plans on the provincial scale, keeping them updated, and sharing them with, and informing, the public opinion with respect to such issues as preparedness, planning, intervening on time and appropriately, managing, and restructuring according to the types of disasters. Planning the issues of threat within integrated corporate governance and integrating these studies with sectoral demands when studying natureand human-induced disaster types have gained

well as 9 university representatives, 3 public representatives, and 5 sectoral representatives in the second meeting ( $9^{\text {th }}$ of March). 
importance in preventive risk determination studies. Since sectoral integratedness and particularly the issues of security and tourism "have been neglected" in terms of the tourism sector, they are evaluated as weaknesses in the SWOT analyses.

Figure 2. Risk Cycle

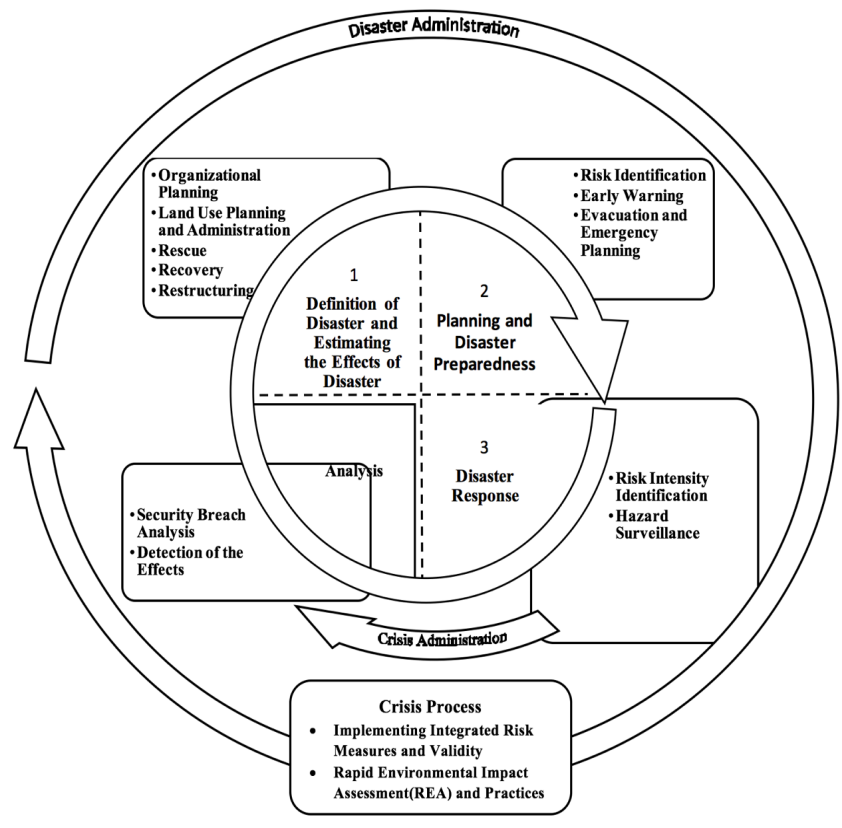

Determination of risky areas and issues; the controlling of natural, technological, social, human, and political conditions; ensuring the development of rational plans, policies, and methods; thinking and directing every detail including the training of decision-makers and implementers; enhancement of awareness and making it adopted as a culture are essential in the planning of the process of risk administration, which also envisages the process of crisis administration (Karaman, 2017, pp. 3-4 ) In this way, the interdisciplinary studies which cover the process "from planning to control" in management, at whose center public administration is present, and which provide the integrity of risk and crisis management are defined as integrated disaster management/administration.

Risk Governance; encompasses the elements of responsibility, legality, impartiality, monitorability, participation, coordination, subsidiarity, effectiveness, and educational awareness and should be taken into consideration at the local and central levels (Sendai Report, 2015) The ethical principles in the reduction of risks have been specified as solidarity, common responsibility, making no discrimination, humanity, objectivity-consistency, impartiality, cooperation, the ability to control land, and the preventive role of the press at disasters. These elements are among the principles of risk and crisis management in the Figure 2.

Besides the service flow of tourism agencies within the ethical behavior codes which are known, which are the subject of international regulations, and which have now acquired a classical value, their importance within the population mobility for various types of tourism and in terms of disaster management, how they manage risk and crisis processes and, if available, their acquired experiences and professionalism that they have developed in providing the security of tourists have gradually become important in the global tourism scenario.

A case: On 3 February 2017, the Louvre Museum was the target of a human-induced terrorist attack. No deadly case from the public or the security units occurred in this event (http://www.telegraph.co.uk/news/2017/02/03/paris). Although more than 1,000 visitors were chosen as a target as a convenient environment for terrorist attacks in agreement with the logic of action of terrorism, the security guards managed the event with great success. However, it is also stated by authorities that the crowded spaces preferred by tourists might become new targets.

The international news channels evaluated the matter as follows within the relationship between "tourism and security". It is seen that naturally and doubtlessly, the reflex of managers is firstly to ensure the security of life and property of settlers and visitors. How the process of crisis that occurred due to terror was perceived and managed by the institutions in the environment and the public administration has been summarized below according to the information obtained by means of the press.

People in the region: They thought that this attack at the Louvre Museum would damage the tourism in Paris and probably cause foreign and French tourists to reconsider when planning to visit this most popular museum of the world.

Public administration: Pierre-Henry Brandet, the spokesman of the Ministry of Interior, shared with the public the information that there were about 1,000 
people at the museum when the attack was organized at about 10.00 a.m. that morning and that they were kept in secure regions before everything was understood clearly. The people were continually provided with information and recommendations about security.

Tourism agencies: Hundreds of university students who had come from abroad and within the country got stuck in the building. However, both the Museum personnel and the agencies informed the families that all students were together and safe. In a letter believed to have been sent to the employees and the guardians, it was mentioned that "By contacting the travel agencies, we would like to inform you that all students and staff members have come together, are safe, and follow the recommendations from the security services".

It was seen that travel agencies had strategic roles in similar communication activities for providing security and social relaxation.

This event truly influenced the interest groups in Turkey in terms of showing that the issue of security was essential in the tourism sector and that the distinction between developed and developing countries disappeared in terrorist attacks. It is seen that the piling up of hundreds of thousands of tourists in the prestige spaces of a country creates an area of interest for terrorists. Distrust of a country, loss of people and economic losses are caused by generating an environment of danger and by creating fear in various crowded spaces of countries. It is predicted that one is predominantly confronted with cross-border terror regardless of its cause and that these threats might continue everywhere, particularly in popular touristic areas (e.g. deadly attack outside United Kingdom Parliament)

(http://edition.cnn.com/2017/03/23/europe/londonattack/). When drawing up strategic action plans in the decision-making process (governance), in which the settled people also take part, it becomes important that the issue of security "in public spaces" should be studied together.

\footnotetext{
${ }^{3} 07$ August 2015, Çaldıran (Van), 2 deaths and 3 injuries, Iranian tour car: https://www.start.umd.edu/gtd/search/ ; 12 January 2016, Sultanahmet (İstanbul) suicide attack, 12 deaths and a suicide bomber, $13 \quad$ injuries (https://tr.wikipedia.org/wiki/2016 Sultanahmet ); 19 March
}

The basic outputs of the above-mentioned brainstorming meetings are as follows. The outputs are firstly concerned with "the overall state of tourism". Secondly, the issue of "security" was acknowledged as an important problem area in terms of sustainable tourism and evaluations of the situation were made ${ }^{3}$. The general opinion of the working group is that the security violations generally have a negative impact on tourism and that the measures to be taken at the national level and the measures that the stakeholders might take on the local scale should be studied multidimensionally and comprehensively and listed individually. Making practices concerning whether the action plans developed were realistic or not and making the information widespread were acknowledged as the basic strategies. The basic issues concerning the subproblem, strategy, and practical action revealing the basic problem area relationship between tourism and security are listed below.

\section{Basis outputs of the brainstorming studies}

1. "Costs" should be examined in the cases of existing and possible impacts of security violations, primarily terrorist attacks, on tourism activities at disasters. Public policies should be drawn up to eliminate and reduce this situation, which prevents tourism.

2. Promotion and security assurance should be evaluated together at the attraction centers for tourism. Today distant accessibility on the Internet is an opportunity, and technological support should be used for the promotion regarding the security of tourism centers.

3. Those regions which are touristic and might be affected by natural disasters should be determined. One should place emphasis on the issue of sound evacuation of tourists and settlers at disasters. Furthermore, the information networks to facilitate accessibility to tourists at disasters should be formed with the participation of sectoral stakeholders.

2016, İstiklal Avenue (İstanbul), 5 deaths, with 4 being tourists and one being the terrorist, 39 injuries (http://www.ntv.com.tr/turkiye/istanbul-istiklalcaddesindepatlama); and 31 December 2016, Reina Attack, 39 deaths 
4. Road security and other security-providing measures during the transportation of tourists are important to the responsible firm.

5. Equipped personnel prepared for disasters should be trained. In-service training concerning the enhancement of the capacity of the personnel should be provided.

6. The personnel to work in the security management of tourism should be indicated as the strategic personnel in the workflow diagram.

7. Although the issue of insurance is essential, currently no insuring format contains any article on "disaster-security-tourism" with respect to disasters. It is important to include this matter in the agenda in insuring.

8. Foreigners cannot be insured in Turkey. The legal deficiency on the matter should be eliminated; there should be institutions or establishments like insurance establishments working to this end; and/or regulations on the matter should be drawn up. The people who come to Turkey arrive as having been insured. However, the phenomena of disasters and terror are not within the scope of insurance.

9. There is no application of a list of visitors submitted to the administration at the entries into ruins and indoor areas. This should be examined.

10. The relationship between a cyberattack and identity is an important matter which should be emphasized in terms of the probability of creating an impairing effect at hotels. In practice, the main reason for asking visitors for an identity is that it is only used to facilitate catching wanted criminals.

11. A political approach which neglects Foreign Tourism but aims at directing oneself to Domestic Tourism and which takes the easy way out is incorrect. Essentially, it does not create the same economic impact either.

12. According to the available data, asylum seekers are not considered a problem area about security.

13. The element of heading for, and curiosity about, undiscovered areas among tourists recently makes the issue of tourism police and security structuring to this end important.
14. One should benefit from the lessons learned of such countries as Egypt and Israel, which have been affected by terror.

15. New multi-stakeholder (governance) units should be established to manage the social perception.

16. It is essential to get rid of the mood which incites the expectation that everything will worsen.

\section{Recommendations-Short Period:}

1. Urban security and security policies should be drawn up.

2. The urban superstructural and infrastructural equipment essential to provide urban security should be planned in a security-providing manner.

3. There is a need for some educational structuring like vocational schools to make the studies on hotel security scientific and to move them to higher levels. No such education is available in Turkey.

4. The provincial directorates of the Presidency of Disaster and Emergency Management (AFAD) give security courses in the training units on tourism in the example of İzmir. These courses should be made widespread in all educational institutions.

5. Tourists are brought to, and left at, hotels but not shown around. Nevertheless, showing the tourists around with the slogan "Let nowhere remain unseen by us" can also trigger new tourist arrivals.

6. Sending the measures about the pre- and postdisaster periods to the mobile phone of each tourist arriving in İzmir is generally included in the evaluation as a good policy at the moment of a disaster. It might be inappropriate to send disaster information when there is no sign; however, spatial praising messages like "safe and beautiful city: İzmir" might be sent to mobile phones. Additionally, information like hospitals might also be sent besides the information like the nearest areas worth visiting and touristic areas.

7. Building security should not be neglected. Information on the security of a building should be provided. This information should be hung onto visible places by developing a specific format.

8. Tourists should be warned against going to insecure places. It should be ensured that attention is paid to these warnings, and the issue of how much 
importance is attached to the warnings by tourists should be examined.

9. Giving security warnings according to the geographical locations of hotels and preparing the security and risk maps of a region (mountainous areas in particular) should be evaluated together with the requirement for a databank.

10. Secure Tourism should be treated as an appropriate theme in the meetings and at the fairs likely to be associated with tourism activities at the national and regional/provincial levels.

11. Regarding the phenomenon of tourism, the sensitivity of the public opinion and of administrators should be ensured and it should be intended to attain the cooperation with public, private, and civil actors in any type of action plan.

12. As service-providing government units, local governments are the strategic and fundamental partners which are closely related to the source of people who are settled and who use the space. They should absolutely take part in the joint studies with the tourism sector.

13. It should be ensured that fundamental principles are drawn up for secure stays (e.g. the possession of "a safe hotel certificate" by accommodation places; giving no damage to the cars, etc. parked in front of a hotel; and the use of technology to provide environmental security by means of MOBESE cameras in terms of its follow-up and checks at entries by means of, for instance, X-ray devices) and that deterrent measures are taken.

14. Agencies and accommodation units should redesign their web pages for security-connected information.

15. Governorship coordination units should take part in the studies on tourism security.
16. It should be ensured that the terminology on security is used and known correctly by subject.

17. The responsibility of the personnel and development of expertise are essential to ensure the efficiency of occupational safety (safety responsibilities) services.

18. It is important to implement the administrative sanction system in all dimensions of security like facility security.

19. In the studies on tourism security, it should be ensured to develop integrated sectoral studies, to consider the issues of corporate social responsibility and work morality important, and to integrate them with these studies. The practices should be checked.

20. It is necessary to collectively perform the checks (internal audit and external audit) concerning the implementation of security-providing action plans associated with the tourism sector. There is a need for external independent control units to perform the external audit.

21. Public service advertisements which also cover classical visual promotion should be created regarding the fact that all requirements for Sustainable Tourism have been fulfilled.

In all these studies, governance - the solidarity of "public, private, and civil partnerships" - is acknowledged as an indispensable method to make use of the knowledge of the society and to obtain the participation and contributions of interest groups in agreement with the philosophy of participation. Below is Table 2, which was prepared in agreement with the philosophy of "active participation, partnership in solution, and solidarity" in the democratic model of Local Agenda 21 (Turkish: Yerel Gündem 21) - the action dimension of the studies of Rio 1992 (Karaman, 2009, pp. 319-344) 
Table 2. Actors of local governance

\section{Local Urban Governance}

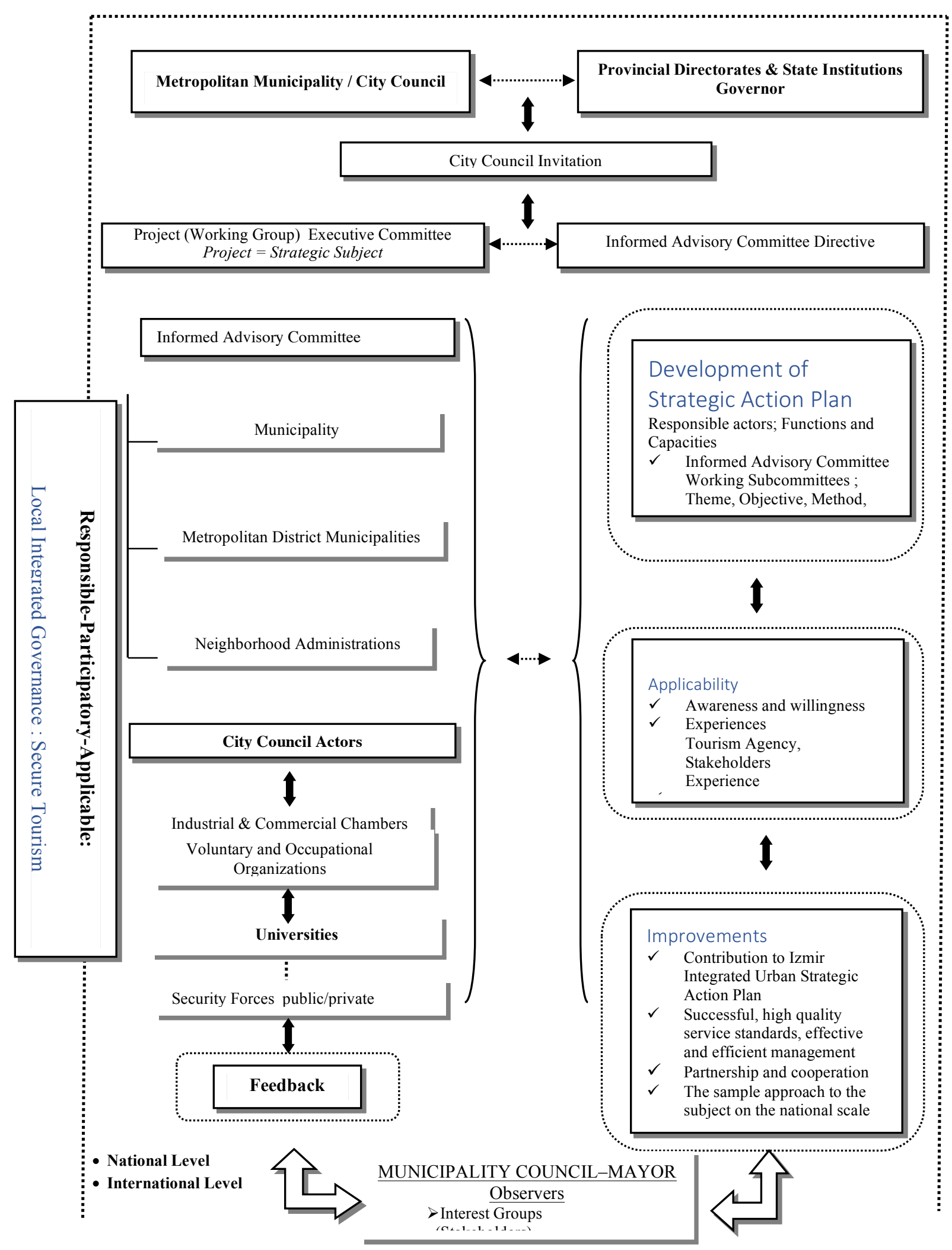




\section{Conclusion and evaluation}

Development of a common policy to achieve a high security quality in tourism: Objectives and action plan governance-oriented extensive impact strategies

In the recent years, 'sustainable secure tourism' has been a common problematic field for most countries whether democratic and developed or not. The integrated strategic action plans on secure tourism have not been developed in Turkey. Therefore, the development of action plans depending on the strategic environmental and human risk analyses and contributing to the social responsibilities is of highest priority as an objective of this subject. Studying the questions of 'What type of strategic model is used on secure tourism?', 'Is it really used?' and 'What kinds of threats are the impacts on Tourism Governance and administration?' are important to obtain the necessary input. It is expected that the studies which increase the social-political awareness and focus on some important problems to create the sustainable healthy tourism can reduce and even eliminate the negative impacts of risks on internal and international tourism activities.

While early forms of tourism studies basically did depend on the fact that "The anthropological sources of environmental pollution should be determined to improve the natural environmental quality which prevents pollution in the touristic area", nowadays considering the impact of worldwide global warming, the development of strategic multi-environmental risk analyses as terrorism and natural disaster as well as both at the same time for each source is a critical research area.

The tools of visual media will be used to create an extensive impact and sustain the attractiveness of public and sectoral personnel awareness on the studies. For this purpose, it is foreseen that the students from the department of Film Design/Cinema in any university or media will shoot per 'target' and 'responsibility' scenarios based on the strategic information and learned lesson information gathered from the studies and written by the stakeholder experts. It is aimed to assure the exhibition of the short and fulllength "public spot films" on the local and national TV channels via the support of related ministries and interest groups.
It is planned to have the students, from the department of graphic design again at any university, if can, prepare the interesting, colorful leaflets and posters showing the institutional and individual responsibilities in sustaining the protection-use balance. It is aimed to create competitive awareness of the secure tourism environment among tourism partnerships and the local people/citizens in the design process of these leaflets and posters.

It is important to create a structure which mainly focuses on cooperation, rather than competition, on sound city policies. The organizations that are formed on the negotiation and cooperation should be used to apply the compromiser politics. Therefore, in the organization of agencies on tourism, it is beneficial to use a legal structure of the partnership between nonprofit and for-profit organizations. It is planned to conduct a survey on the multidirectional recognition of problems and the determination of solution-oriented contributions by using these tourism agencies especially on the popular touristic district and the coastline destination and mountainous-rural areas. The meetings will be held to increase the awareness for involving in common action plans through negotiating secure tourism for the applicability of the solutionoriented scenarios. Using the synergy created in these meetings, it is aimed to provide intellectual support to the stakeholders in touristic agency about attaining the objectives of an integrated project for secure touristic areas.

The informed members of the Regional Development Agency and the other public, private and non-governmental actors will be encouraged to determine the strategic plans which aim at regional development and improvement of the social capital, and form objectives and action plans in the negotiating of secure city environments.

The general characteristics of the settlement place in the service region of the selected pilot agency/agencies in each country and in Turkey, the contributions of agency to the region, the SWOT analyses, the interests of other neighbor agencies and their responsibilities and the necessary conditions for integrated cooperation will be assessed. 


\section{Other possible investigations}

What are the main characteristics of touristic activities? What are the impacts of the settlement and touristic activities around the touristic areas? What is the importance of risk and crisis analyses on touristic areas for secure tourism? Are there any risk regional maps on different types of threats? Can they be prepared? What is the importance of safe security activities like telecommunication, personnel capacity, and capability? Is there any risk plan and management process in a risky situation?

What types of tools will be developed to create a Corporate Social Responsibility-oriented, integrated secure touristic management program? What can be done to create a realistic model which is beyond all hesitations, valid for the global case, and based on the international agreements? What should be the survey questionnaire that focuses on the objectives of the project, creates a capacity of producing inputs that can set the social capital into action, and provides institutional and personal awareness?

\section{The threats}

Individuals and institutions, in an interactional manner, might sometimes be against the declared visible security projects in Turkey. A project may not be supported politically. What can be the strategies for eliminating the dispiriting people or conflicting opinions that negatively affect the integrated working and negotiation environment? To achieve this objective, it is important to interview and share the positive impacts of this subject with the influential opinion leaders, village headmen, and mayors in the selected pilot regions at the first step.

\section{References}

Karaman, Z.T. (2009). "Democratic Gains in Public Administration at Local Level in terms of CSR: Theoryand Practice-Based Approaches- Turkey and Izmir Metropolitan City", Idowu, S. O ve Walter, L. F.(Eds.), Professionals' Perspectives of Corporate Social Responsibility, London, Springer.

Karaman, Z.T. (2017). "Afet Yönetimine Giriş ve Türkiye'de Örgütlenme", Karaman, Z.T and Altay, A.(Eds),(2017), Bütünleşik Afet Yönetimi,İzmir, Birleşik Press, Second Published.

Kôvári, I. and Zimányi, K. (2017). "Safety and Security in the Age of Global Tourism", table, 1, http://ageconsearch.umn.edu/bitstream/104672/2/10 K ovari Safety Apstract.pdf access 19.03.2017

Maniruzzaman,T. (1982). The Security of Small States in the Third World

http://bellschool.anu.edu.au/sites/default/files/publicatio ns/attachments/2016-03/sdsc-maniruzzaman.pdf access 14.03.2017

Sendai Framework for Disaster Risk Reduction (2015-2030) (2016). http://www.unisdr.org/we/coordinate/hfapost2015 access 23.10.2016

UNDP Human Development Report of 1994 (2017). http://hdr.undp.org/sites/default/files/reports/255/hdr 1 994 en complete nostats.pdf access 20.04.2017

07 August 2015, Çaldıran (Van), 2 deaths and 3 injuries, Iranian tour car:

European Forum for Disaster Risk Reduction Report (EFDRR), On Governance and Accountability of the Hyogo Framework for Action (2014). https://www.unisdr.org/we/inform/publications/39593 access 23.10.2016

file://C:/Users/Asus/Downloads/SurdurulebilirTurizmrapor\%20(1).pdf access 3.03.2017

Hague Declaration on Tourism, 1989; http://www.eunwto.org/doi/pdf/10.18111/unwtodeclarat ions.1989.15.4.1 access 19.03.2017

http://edition.cnn.com/2017/03/23/europe/london-attack/ access March 22, 2017

http://www.inform-index.org/Countries/Countryprofiles/iso3/TUR 2017 access 20.04.2017

http://www.nfi.at/dmdocuments/NachhaltigerTourismus E N.pdf access 3.03.2017

http://www.ntv.com.tr/turkiye/istanbul-istiklalcaddesindepatlama access 31.12.2017

http://www.telegraph.co.uk/news/2017/02/03/paris3.3.2017

http://www.turizmdebusabah.com/haberler/kruvaziyerturizmi-icin-2017-daha-da-kotu-gececek-82552.html access 20.03.2017

http://www.tursab.org.tr/dosya/15049/aralik201615049 5443998.pdf access 3.03.2017

http://www.tursab.org.tr/tr/turizmverileri/istatistikler/turizmin-ekonomideki-yeri/gsmhicindeki-payi-1963- 79.html access 25.03.2017

http://www.un.org.tr/2017-international-year-ofsustainable-tourism-for-development/ access21.04.2017 http://www.un.org/en/ga/search/view doc.asp?symbol=A/ RES/70/193\&referer=/english/\&Lang=E 3.03.2017

http://www.un.org/en/sc/repertoire/89 92/Chapter\%208/GENERAL\%20ISSUES/Item\%2029 Agenda $\% 20$ for $\% 20$ peace .pdf access 3.03.2017

http://www.un.org/humansecurity/sites/www.un.org.human security/files/chs final report - english.pdf 14.03.2017

http://yigm.kulturturizm.gov.tr/TR,72942/turizm-gelirgider-ve-ortalama-harcama.html access 25.03.2017

https://tr.wikipedia.org/wiki/2016 Sultanahmet sald\%C4

$\% \mathrm{~B} 1 \mathrm{r} \% \mathrm{C} 4 \% \mathrm{~B} 1 \mathrm{~s} \% \mathrm{C} 4 \% \mathrm{~B} 1$ access 31.12 .2016

https://www.start.umd.edu/gtd/search/ access 31.12.2016 